\title{
Extraction of Two Sill Pillars Under Paste Backfill at Louvicourt Mine, Canada
}

\author{
C. Doucet, Natural Resources Canada, CANMET Mining and Mineral Sciences Laboratories
}

S. Lampron, B. Bisson, R. Harrisson, Aur Resources, Louvicourt Mine, Canada

\section{INTRODUCTION}

Louvicourt Mine, located approximately $500 \mathrm{~km}$ north-west of Montreal, Quebec, Canada, is co-owned by the operator Aur Resources inc. (30\%), Teck Corporation (25\%) and Novicourt (45\%). The polymetallic orebody $(\mathrm{Cu}-\mathrm{Zn}-\mathrm{Au}-\mathrm{Ag})$ was mined between depths of 400 and $920 \mathrm{~m}$ for 11 years and the mine closed in July 2005. Extraction of the orebody started from the $655 \mathrm{~m}$ and $860 \mathrm{~m}$ levels using a primary/secondary ascending mining sequence with paste backfill. Extraction on two levels created a 600000-t sill pillar between the 655 and 680 levels. Extraction below the 860 level created a second sill pillar $(230000 \mathrm{t})$ between the 860 and 885 levels. These two pillars are located under paste backfill and the rockmass in those areas is highly fractured as a result of high mining stresses. Since the backfill was poured at the beginning of the mine's operation, the mixes used were not optimal and the fill quality was variable. This paper describes the steps taken to design the mining of the stopes under paste and the results obtained for both sill pillars.

\section{DRILL DRIFTS DESIGN}

It was decided to mine downhole stopes using a longhole mining method and a primary/secondary sequence. Access to the stopes was required at the top of the sill pillars, this was achieved using two different methods: drifting under paste for the sill pillar on the 680 level and drifting through paste for the 885 level sill pillar.

\subsection{Drifting through paste (885 Sill Pillar)}

Drifting through paste is not as desirable an option, since all the excavated paste needs to be handled and stored. In addition, back and wall controls are extremely difficult in poor quality paste. However, the main advantage of this method is that drifts are located at the same elevation as the main drift. When the main drift is located close to the ore reserves, drifting through paste is the only viable option. This method diminishes risks associated with elevated ground stresses and seismicity. Fewer and shorter drill drifts were needed for the 885 sill pillar than for the 680 sill pillar as fewer reserves were available. It was also easier to dispose of the excavated paste. 


\subsection{Drifting under paste (680 Sill Pillar)}

With drifting under paste, development is almost exclusively in ore, while being far enough away from high seismic risk zones. The rockmass in these areas was extremely fractured. These drill drifts start at the main drift level and ramp down to a minimum of $3.5 \mathrm{~m}$ below the paste of the overlying stopes. Reserves need to be far enough from the main drift in order to ramp down safely. Figure 1 shows a typical development face.

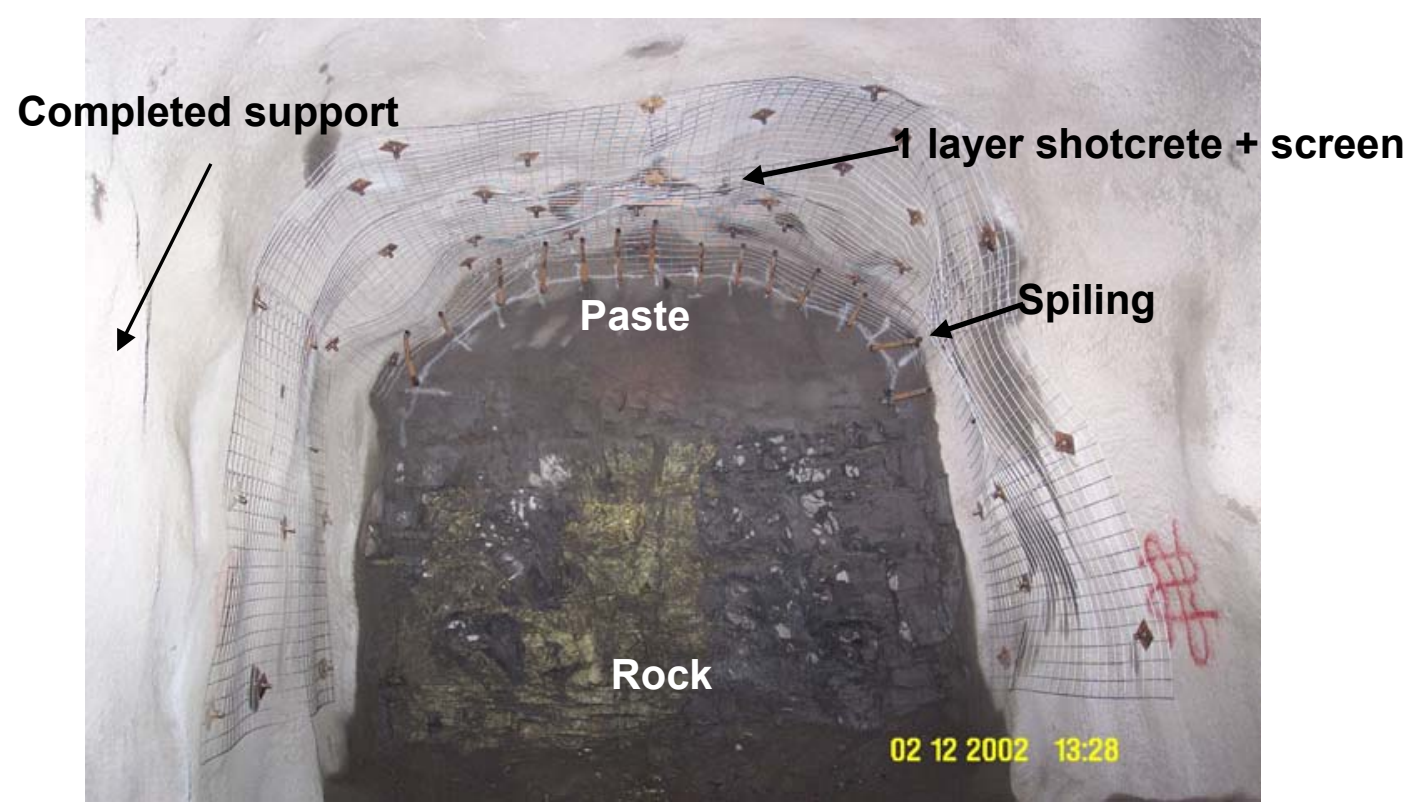

Figure 1 Typical development face under very poor quality paste in the 680 sill pillar

Table 1 Support with respect to paste quality and excavation geometry

\begin{tabular}{|c|c|}
\hline $\begin{array}{l}\text { Backfill } \\
\text { Quality }\end{array}$ & Geometry of opening and support used \\
\hline Good & $\begin{array}{l}\text { Arch not necessary (flat back) } \\
2 \times 2 \text {-inch layers of shotcrete* } \\
\text { Weld wire mesh screen between shotcrete layers: } 1 / 2 \text { wall height when under paste and full } \\
\text { height when in paste }\end{array}$ \\
\hline Poor & $\begin{array}{l}\text { Arched drift with radius }=3.25 \mathrm{~m} \\
2 \times 2 \text {-inch layers of shotcrete with weld wire mesh screen in between: } 1 / 2 \text { wall height when } \\
\text { under paste and full height when in paste }\end{array}$ \\
\hline $\begin{array}{l}\text { Very } \\
\text { poor }\end{array}$ & $\begin{array}{l}\text { Arched drift with radius }=3.25 \mathrm{~m} \\
2 \times 3 \text {-inch layers of shotcrete with weld wire mesh screen in between: } 1 / 2 \text { wall height when } \\
\text { under paste and full height when in paste } \\
\text { Spiling is used for very poor paste }\end{array}$ \\
\hline
\end{tabular}

Shotcrete mix used included 3.5\% accelerator to ensure $20 \mathrm{MPa}$ after 12 hours and screen was bolted with Swellex bolts on a $1.3 \mathrm{~m}$ by $1.3 \mathrm{~m}$ pattern. 
Prior to drifting, drain holes were drilled from the 680 level to the paste above 655 level to enable seepage of water trapped between paste and rock and ultimately drainage of paste. In addition, each planned drill drift back was sampled with a diamond drill hole in order to determine the quality of the paste to be encountered. The access support design was based on the paste quality (Table 1). An intensive quality control program was established to ensure that arch shapes and specified radii were used when drifting in poor to very poor quality paste. Average drifting costs were approximately twice as much as drifting in rock $(2000 \mathrm{Cdn} \$ / \mathrm{m})$. Costs were estimated at $4350 \mathrm{Cdn} \$ / \mathrm{m}$ and $5250 \mathrm{Cdn} \$ / \mathrm{m}$ in good and poor quality pastes, respectively.

\section{STOPE DESIGN}

Stope design was intended to limit paste caves from the stope backs. Any cavity that might form would be very difficult to backfill since all openings on the above levels were already backfilled. Therefore, paste characterization was a critical step in stope design.

\subsection{Paste fill properties}

Table 2 summarizes the results from the triaxial characterization studies for paste diamond-drilled samples obtained from the stopes on the 655 level. Diamond drilling was performed using as little water as possible and samples were wrapped in cellophane until logged and tested. Paste that could not be sampled was characterized as of a very poor quality. Pictures of good and poor quality paste are shown in Figure 2 . The percentage of mined stope lengths for both sill pillars located underneath each fill quality is also shown. More than half of the reserves of the sill pillars were located under very poor quality paste poured at the beginning of the operation when the fill plant was going through commissioning and optimisation of the fill mixes was going on. However, stopes backfilled after 1995 contain good to excellent quality pastes.

Table 2 Mechanical properties determined for various paste qualities

\begin{tabular}{|l|c|c|c|c|c|}
\hline Paste quality & $\begin{array}{c}\mathrm{E} \\
(\mathrm{MPa})\end{array}$ & $\begin{array}{c}\phi \\
(\mathrm{deg} .)\end{array}$ & $\begin{array}{c}\mathrm{c} \\
(\mathrm{kPa})\end{array}$ & $\begin{array}{c}\mathrm{UCS} \\
(\mathrm{kPa})\end{array}$ & $\begin{array}{c}\text { Percentage of sill } \\
\text { pillar stope lengths }\end{array}$ \\
\hline Excellent & 250 & 30 & 1250 & 4300 & $27 \%$ \\
\hline Good & 250 & 30 & 875 & 3000 & $17 \%$ \\
\hline Medium & 250 & 30 & 500 & 1700 & $56 \%$ \\
\hline Poor & 100 & 30 & 100 & 345 & 35 \\
\hline Very poor & 0 & 12 & 10 & & \\
\hline
\end{tabular}




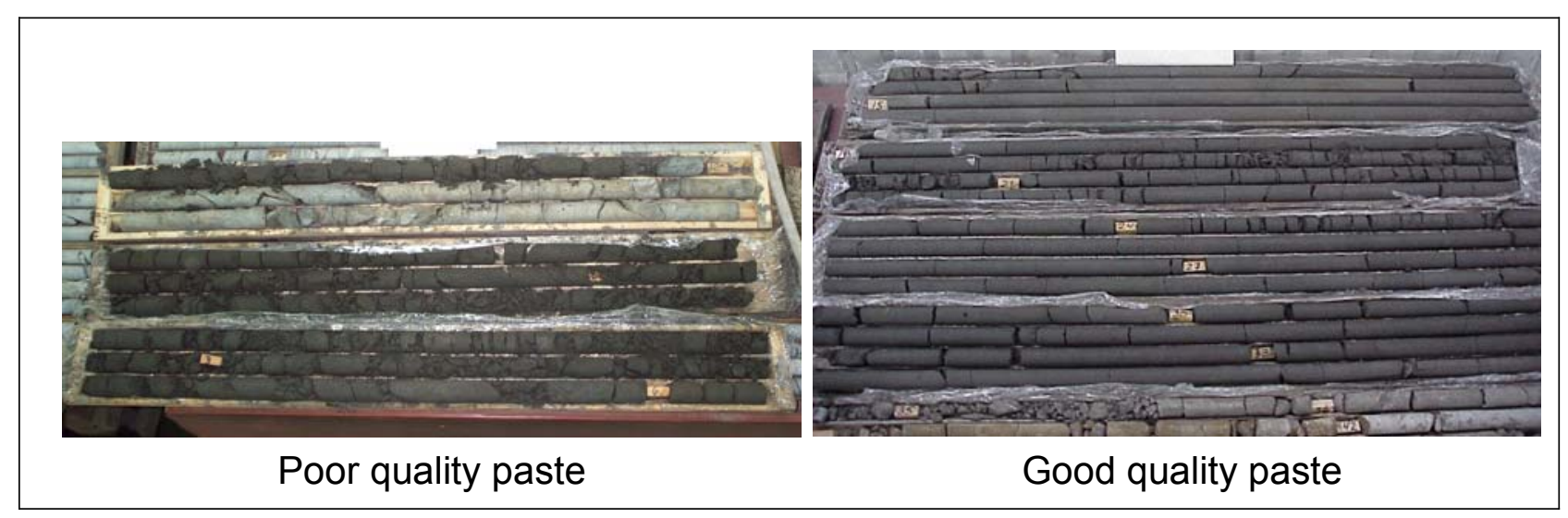

\section{Figure 2 Pictures of poor and good quality pastes}

\subsection{Stope dimensions}

Numerical modelling was used to determine the stope dimensions. Primary and secondary stope widths were fixed at $15 \mathrm{~m}$. Stope lengths, under varying paste quality, were modelled to determine optimal stope configurations.

\subsubsection{Primary stopes}

The primary stope design was relatively simple, since they are surrounded by rock on two sides. Initially, a skin pillar was left in the stopes located under poor quality paste. Modelling revealed that regardless of paste quality, the stope back would remain stable as long as drift pillars located on each side of the drill drifts were stable and shotcrete was used. Special care was taken when blasting the stopes to ensure the stability of the drift pillars, which would ultimately be crucial for the stability of the secondary stopes. This was achieved by using emulsion explosives and electronic caps. Figure 3 shows the primary stope designs for both sill pillars.

\subsubsection{Secondary stopes}

The secondary stope design considered many aspects: paste quality in the stope back, stability of the drill drift pillars in the adjacent stopes, in both the transverse and longitudinal directions. Three modified configurations were modelled using 3DEC (Andrieux and O'Connor, 2004).

Of the three scenarios proposed, a combination of configurations 1 and 2 was used (Figure 4). A 4-m thick, arched skin pillar was designed, as opposed to the 2-m thickness modelled (Figure 5). The main disadvantage with this pillar design is that its stability depends on the degree of rockmass fracturing. To increase its stability, 4-m long cables were inserted between drilling rings for a $3 \mathrm{~m}$ by $2 \mathrm{~m}$ pattern. In the long accesses (where many stopes needed to be mined, such as panels 26 and 28 of the 680 sill pillar), 6-m thick transverse pillars were located in less fractured and lower grade zones. 


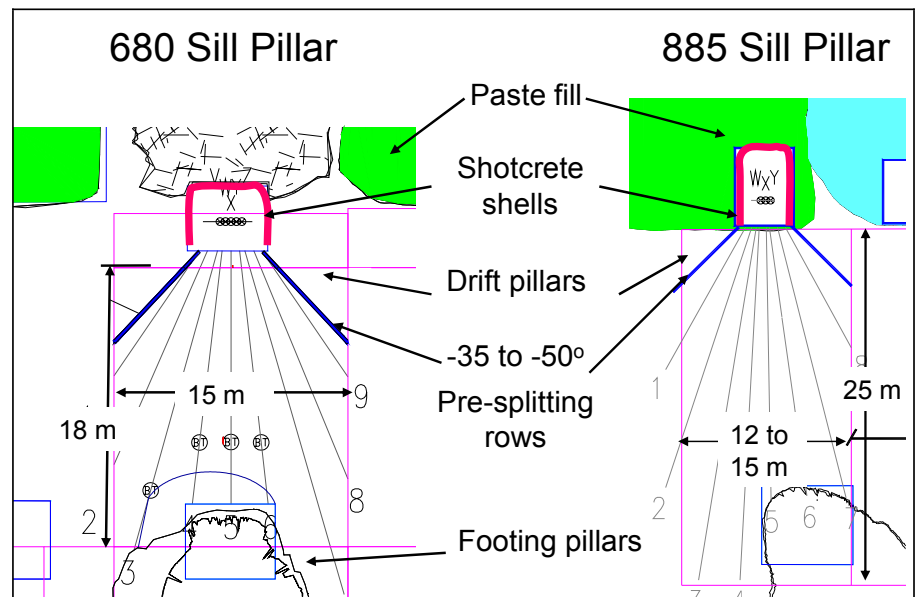

\section{Figure 3 Primary stope designs - East-West sections looking North (not to scale)}

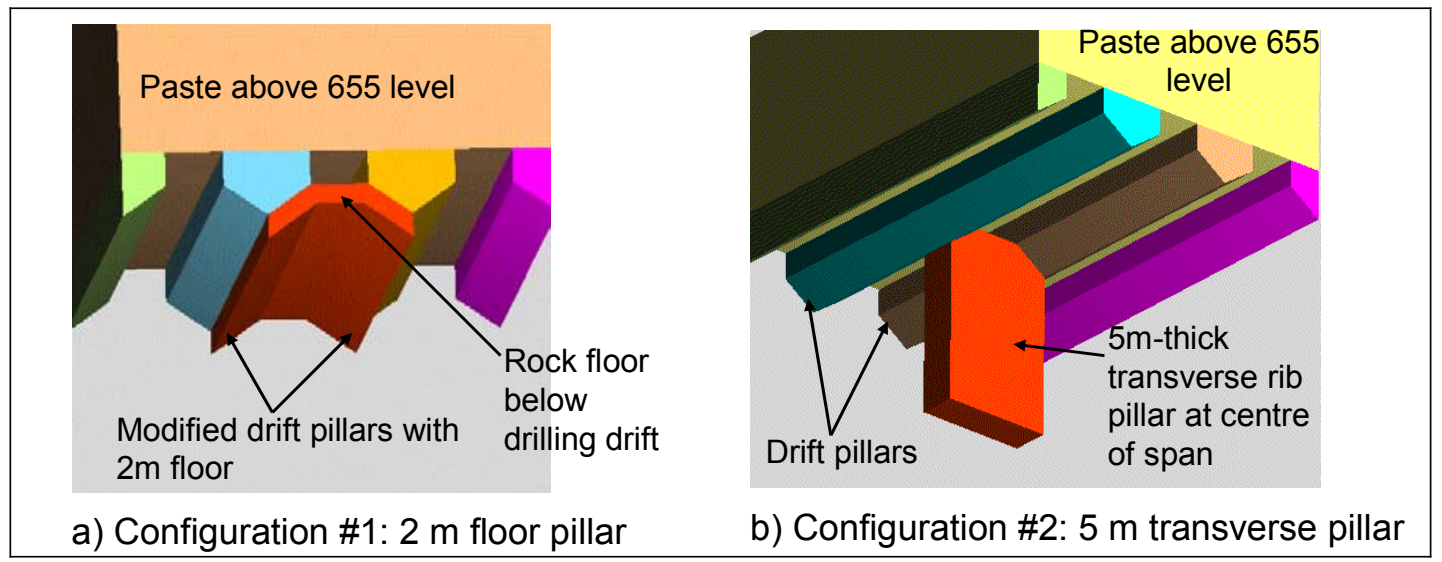

Figure 4 Secondary stopes configurations modelled with 3DEC (after Andrieux and O'Connor, 2004)

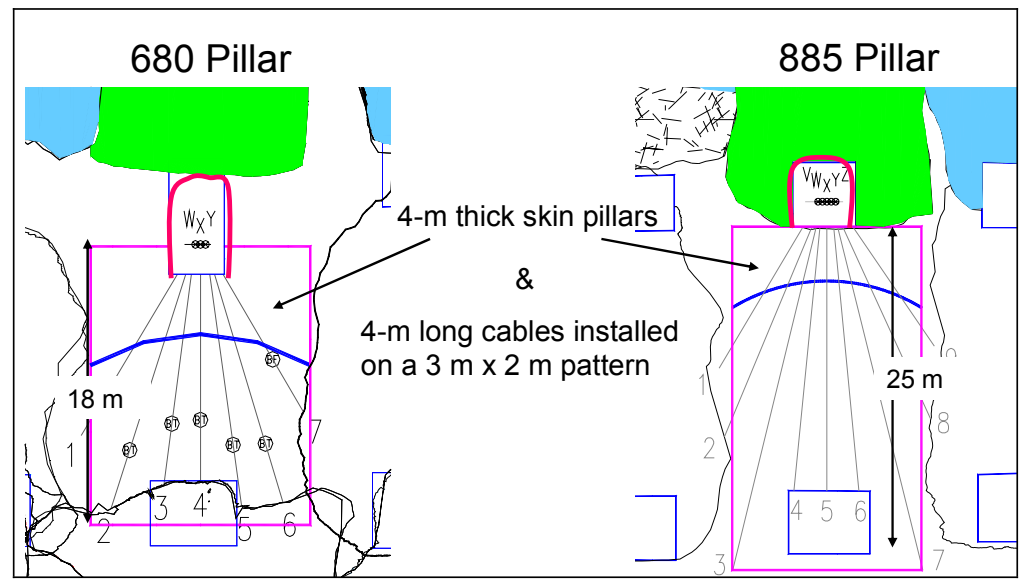

Figure 5 Secondary stope designs - East-West sections looking North (not to scale)

Stope lengths were determined with the help of numerical modelling results. The original $15-\mathrm{m}$ length was later increased beyond the modelling results, as the mine gained experience and confidence with mining secondary stopes under paste. A risk assessment was performed on the probability of failure of the skin 
pillar and the shotcrete shell. The shotcrete shell designs having a high factor of safety, it was felt that the probability of complete failure was low. In order to evaluate the worst case scenario i.e. if complete skin pillar failure and the shotcrete shell rupture were to occur, thus exposing backfill in the back on the entire stope width $(15 \mathrm{~m})$, a model of an open secondary stope with various paste qualities in the back was constructed. Stable exposed fill lengths on a width of $15 \mathrm{~m}$ were determined for various paste qualities and the results plotted in Figure 6. It shows that a poor quality paste can be exposed on surface of $15 \mathrm{~m}$ by $6 \mathrm{~m}$. Paste was exposed in only two occurrences which are discussed in the next section.

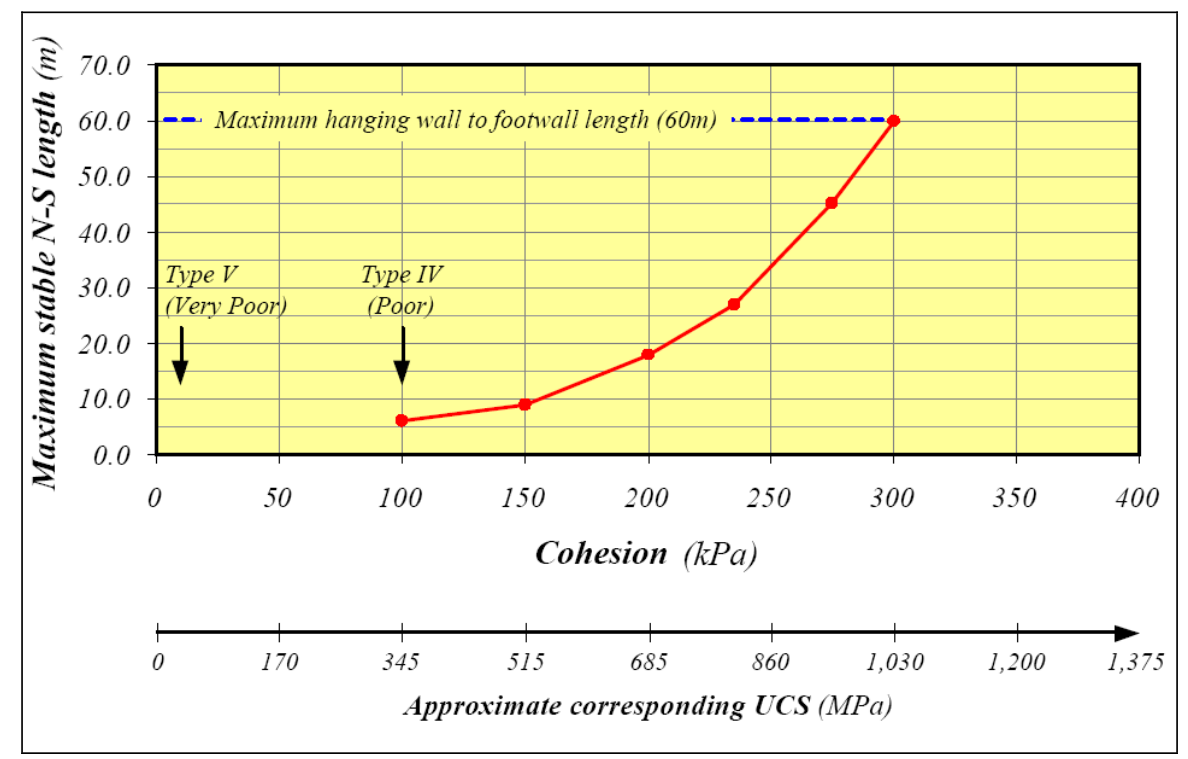

Figure 6 Evaluation of stable secondary stopes lengths (after Andrieux and O'Connor, 2004)

\section{RESULTS}

On June 16, 2005 Louvicourt Mine's last stope was blasted. The mine officially ceased production operations on July 12, 2005. The following sections describe the results obtained for primary and secondary stopes only, i.e. upper and semi-secondary stopes (those with only one primary on one side) are not included in the discussion.

\subsection{Primary stopes}

In general, the extraction of the primary stopes was a success for both sill pillars. Recoveries of $91 \%$ and $69 \%$ were obtained for the 680 and 885 sill pillars, respectively (Table 4). Very good dilution levels of under $10 \%$ were obtained. This success is primarily due to the optimization of blasting practices and to the design of the support of the drill drifts, specifically the shotcrete shells design (Harrisson, 2003). Statistics from the 885 sill pillars are less representative as fewer stopes were mined in this pillar. The lower recovery means that ore remained on the walls of the primary stopes, but was later recovered with the secondary stopes. 


\begin{tabular}{|l|c|c|c|}
\hline Pillar & Number of stopes & \% recovery & Dilution \\
\hline \hline 680 & 19 & $91.3 \%$ & $4.5 \%$ \\
\hline 885 & 4 & $69.2 \%$ & $8.2 \%$ \\
\hline
\end{tabular}

\subsection{Secondary stopes}

Table 5 shows that secondary stope recoveries were over $93 \%$. For both pillars, dilution is under $20 \%$ and is associated with paste failure / caving from the adjacent stopes. The following section describes some of the problems encountered and the solutions developed during the mining of the secondary stopes. The discussion mostly covers the extraction of the 680 sill pillars, since this is where most of the reserves were located and, consequently, where most of the problems occurred. No major problems occurred and no rehabilitation of the access drifts was needed during the extraction of the 885 sill pillar since the walls were in backfill and hardly any fracturing of the shotcrete shell occurred. It should be noted that more than half of the secondary stopes, in the 680 sill pillar, were located under very poor to poor quality paste.

\section{Table $5 \quad$ Secondary stopes recovery and dilution rates}

\begin{tabular}{|l|c|c|c|}
\hline Pillar & Number of stopes* & \% recovery & Dilution \\
\hline \hline 680 & 8 & $93.5 \%$ & $16.4 \%$ \\
\hline 885 & 3 & $95.7 \%$ & $19.2 \%$ \\
\hline
\end{tabular}

* Table includes only true secondary stopes (no upper or semi-secondary stopes).

\subsubsection{Problems encountered during secondary stopes extraction}

Extraction of the secondary stopes in the 680 sill pillar started in May 2004 and finished in June 2005. The major problem encountered during secondary stopes extraction was dealing with delays, in the already-tight mining sequence, in order to ensure that the planned reserves for the final operating year were mined. Delays were mostly due to the rehabilitation of some drill drifts where the shotcrete shell was fractured by movement of the rock in the walls after blasting. Rehabilitation consisted in either covering the damaged area with screen or applying a new layer of shotcrete, depending on the severity of the damage.

No skin pillar was planned for the first secondary stope (stope 6828-1) as it was partially located under a 2-m thick slab of rock that was judged sufficient to establish a stable back. Stope 6828-1 was blasted in one shot with electronic caps. Figure 7 shows the location of panels 26 and 28 on the 680 level (a), a North-South section through Panel 28 (b) and a larger plan view of Panel 28 (c). Since the rockmass was extremely fractured in this area, the blast resulted in the appearance of many open fractures (Point A - in Figure 7) in 
the shotcrete of the drill drift on the 655 level as well a major fracture in the floor of the drill drift. A portion of the adjacent stope in the panel (block 2) caved during the blast (Point B - in Figure 7). The footing pillars on the 680 level of block 2 and part of block 3 were missing (Point $\mathrm{C}$ - in Figure 7) i.e. the drill drift pillars of the underlying stopes $(7128-1 \& 2)$ had caved when the stopes were blasted. The presence of major fractures and the missing footings combined to create an unstable block. An action plan was developed to remedy the situation:

- Apply a new layer of shotcrete on the back and walls of the shotcrete shell in the access on the 655 level.

- Pile up muck along the walls in the mucking drift (680 level) under block 2 to compensate for the missing footing pillars. The muck provided support, although not as rigid as rockmass, to the unstable block. It was recognized that the muck would let the block move to a certain extent, but it was felt that it would prevent its failure.

- Install an extensometer in the top of 6828-3 to monitor its movement.

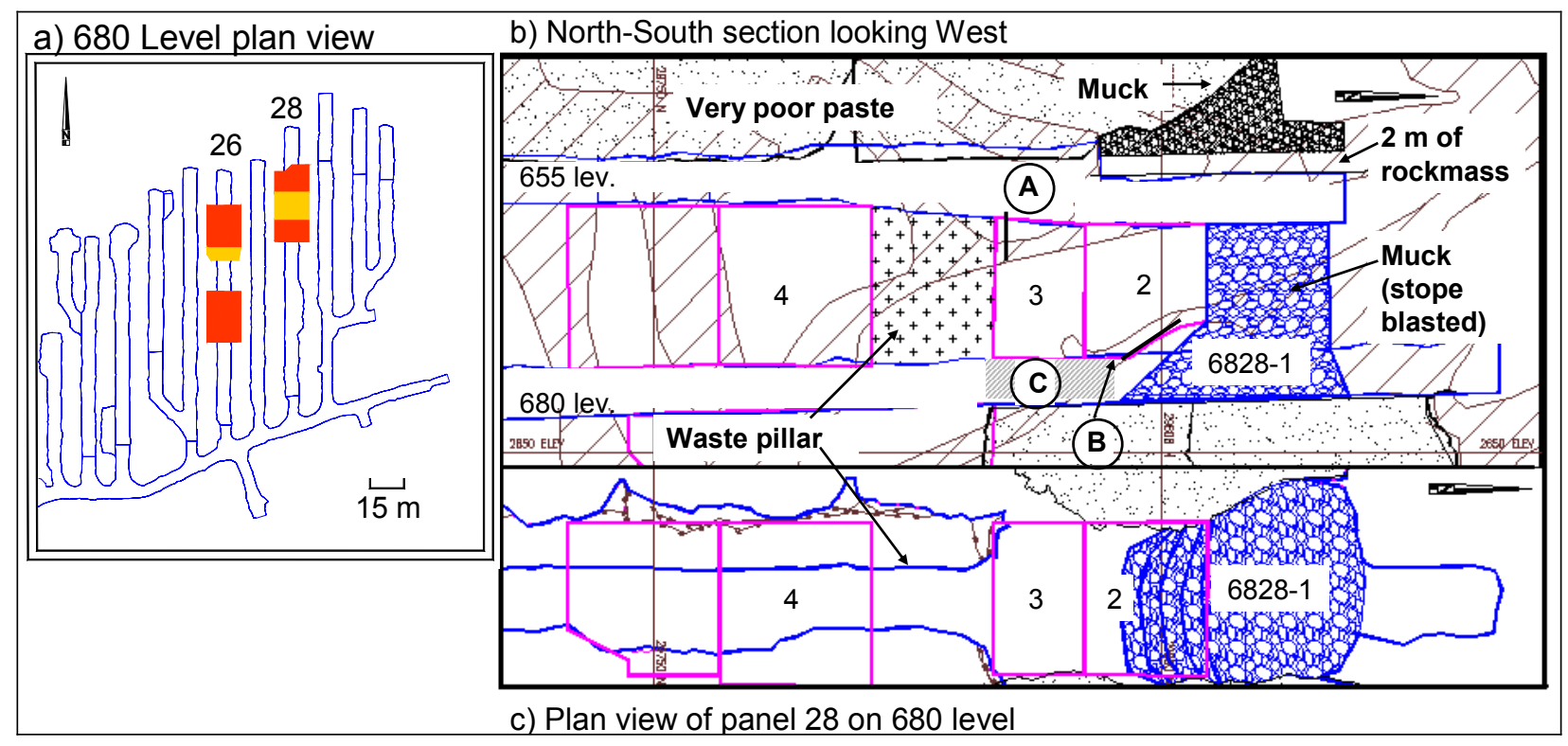

Figure $7 \quad$ Results of the blast of stope $6828-1$

The problems encountered had major consequences. The rehabilitation caused important delays in the mining sequence and a more profitable stope could not be mined. As a result, stope 6828-1 was not mucked out, 6828-2 left in place as a transversal pillar and 6828-3 mined. Stope 6828-3 was $9 \mathrm{~m}$ long with an arched $4 \mathrm{~m}$ thick skin pillar at its centre. The skin pillar remained stable and the muck piled under block 2 provided the support needed for the duration of the extraction of the stope.

Extraction of the first secondary stope enabled the identification of potential problems for the following secondary stopes. Based on this experience, an action plan was established and followed before proceeding with the extraction of the subsequent secondary stopes: 
- Review of all subsequent secondary stopes in order to verify the condition of the footing pillars along the access drift and plan alternative support if needed.

- Verify the condition of adjacent stopes drift pillars (i.e. stopes along strike) and plan backfilling of primary stope accesses on the 655 level in order to reinforce the drift pillars.

- Inspect drill drifts to determine possible rehabilitation needs.

- Plan installation of extensometers in subsequent transverse stopes (i.e. stopes located south of the planned stope in the same access) in order to monitor potential movements in these blocks during mucking.

Important delays in the mining sequence of the 680 sill pillar forced the engineering department to revise the mining plan for many secondary stopes. To compensate for this, mining experience was used in order to increase the length of the stopes. In some panels, it was possible to combine stopes when the rockmass was relatively massive. In others, the stopes were blasted into the underlying open stope and backfilled altogether. An example of this is the stope 6826-2 (Figure 8) which was blasted into stope 7126-3 and mucked out from the 710 level.

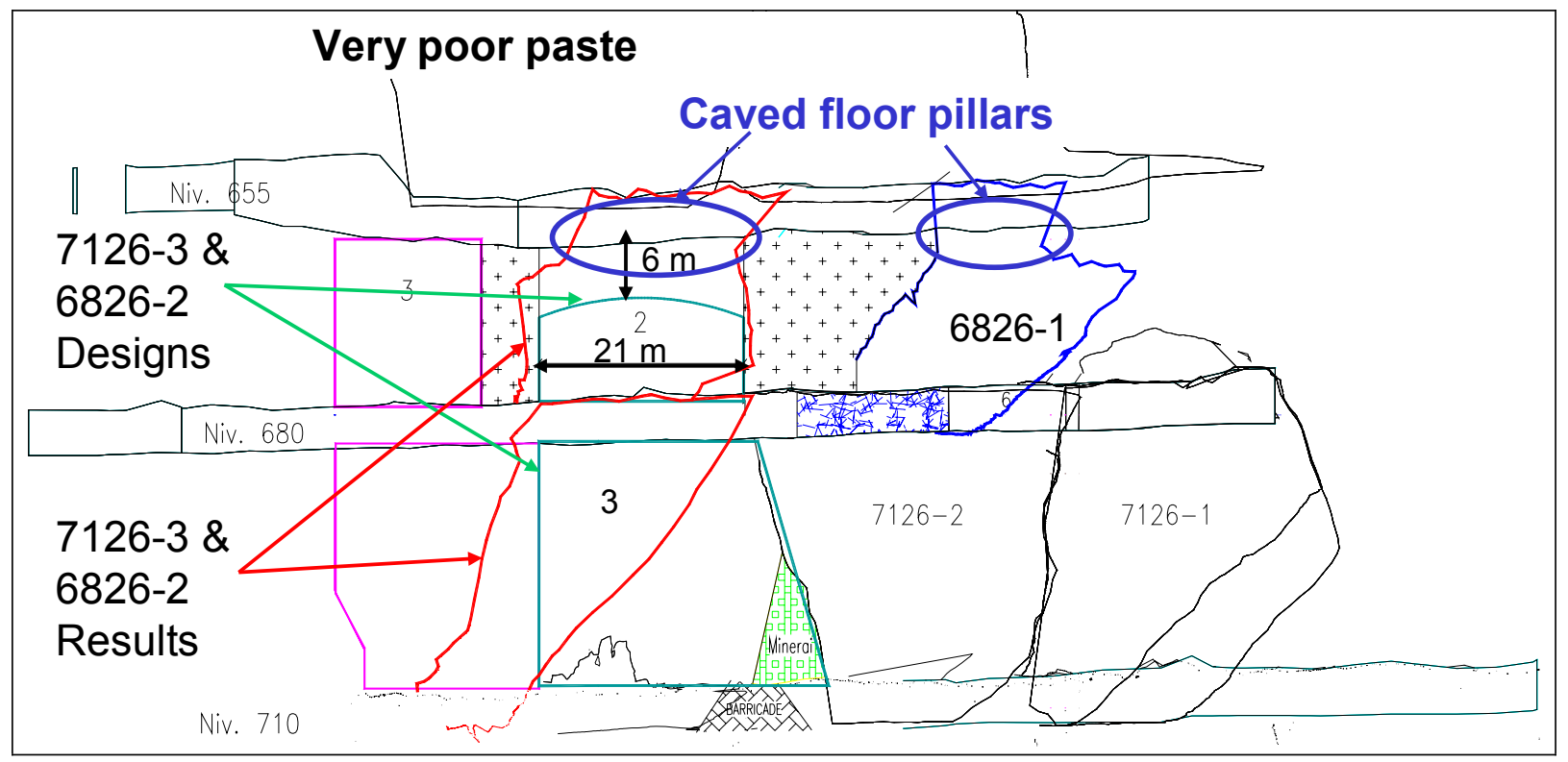

Figure 8

Initial and final designs of the extraction of Panel 26 (North-South section looking West).

The only major failures of the shotcrete shells occurred in Panel 26. The skin pillar of stope 6826-1 caved over a length of $11.5 \mathrm{~m}$ and subsequently caused the failure of the shotcrete shell east wall over a 6-m length three days later. The very poor quality paste exposed and the rest of the shotcrete shell remained relatively stable. The skin pillar of stope 6826-2 caved over an 18-m length between two major fracture zones. Approximately eight days later, the east wall of the shotcrete shell ruptured and exposed the very poor quality paste located in the back over an $8 \mathrm{~m}$ long by $10 \mathrm{~m}$ wide section, which started caving. Figure 6 
showed that a surface of $15 \mathrm{~m}$ by $6 \mathrm{~m}$ of exposed paste with cohesion of $100 \mathrm{kPa}$ (poor quality) would remain stable. The dimensions exposed by the 6826-2 failure were less than those specified in the model but paste quality was poorer. The rest of the shotcrete shell remained stable.

The skin pillar helps to maintain the drift pillars when it remains stable after blasting. However, if the skin pillar ruptures, parts of the already-fractured drift pillars could eventually cave and, in turn, cause the partial rupture of the shotcrete shell. Increasing the skin pillar thickness to compensate for fracturing does not significantly increase stability. Therefore, existing fracture zones play an important part in the stability of the stopes. For these reasons, it was agreed that if there was a risk of skin pillar caving, it was preferable to mine the stope without leaving a skin to allow for better control of the drift pillars by using pre-split blasting to increase their chances of remaining stable for the duration of stope excavation. Stope 6815-4 was mined over a 30-m length without a skin pillar, as the drift pillars were extremely fractured and the risk of skin pillar caving was high. The shotcrete shell remained stable over its entire length for the duration of the stope extraction.

\section{CONCLUSIONS}

The extraction of the two sill pillars was a huge success mainly due to the incredible efforts of everyone involved to ensure that the best designs, based on the available knowledge, were used. Many studies were undertaken and, as the mine gained experience and confidence with mining sill pillar secondary stopes, their results were used to continuously improve the designs.

The choice of drifting through or under paste had both advantages and disadvantages, namely, the rehabilitation of the drill drifts on the 655 level and the disposal of the excavated paste on the 860 level. Rehabilitation caused major delays in the mining sequence. However, the solutions used to remedy the delays made it possible to extract all the planned reserves with higher recovery rates than originally planned. Mining costs for sill pillar extraction were marginally higher than in other areas of the mine. The mine's success in mining the sill pillars allowed for the addition of unplanned stopes into the mining sequence.

\section{ACKNOWLEDGEMENTS}

The authors are especially grateful for the help of the mining and engineering departments of Louvicourt Mine without whom the extraction of the sill pillars would not have been the success that it was. The authors also wish to thank Aur Resources - Louvicourt Mine for the opportunity to present this work.

\section{REFERENCES}

Andrieux, P. and O'Connor, C. (2004) 3DEC Modelling of the recovery of secondary panels in the 680 sill pillar at Louvicourt Mine, Itasca Consulting Canada, presentations to the mine on December 13 2003, January 16 and February 16.

Harrisson, R. (2003) Développement dans/sous le remblai en pâte à la Mine Louvicourt. Recueil des conférences du $18^{\mathrm{e}}$ Colloque en contrôle de terrain, Association minière du Québec, 18 et 19 mars. 